Firdaus, W., \& Arjanggi, A. (2020). Self-efficacy and career decision making difficulties in senior high school students. Indigenous: Jurnal Ilmiah Psikologi, 5(2). 141-150. doi: https://doi.org/ 10.23917/indigenous.v5i2.8941

\title{
Self-Efficacy and Career Decision Making Difficulties in Senior High School Students
}

\author{
Wahyuningtyas Firdaus ${ }^{1}$, Ruseno Arjanggi ${ }^{2}$ \\ Fakultas Psikologi, Universitas Islam Sultan Agung 1,2 \\ wahyuningtyasfirdaus97@gmail.com ${ }^{1}$, ruseno@unissula.ac.id ${ }^{2}$
}

\begin{abstract}
This research aims to determine the correlation between self-efficacy and career decision-making difficulties in senior high school students, also to determine the differences in career decision-making difficulties between public school students and private school students. The dependent variable was career decision-making difficulties, and the independent variable was self-efficacy. This research used a quantitative method. The samples analyzed were 193 students of senior high school $N$ and $S$ in Semarang. The data collection of this study used methods of career decision-making difficulties questionnaire and scale of self-efficacy. Career decision-making difficulties questionnaire amounted 38 items with item-total correlation 0.380-0.768 and internal consistency equaled to 0.960. The scale of self-efficacy amounted 29 items with item-total correlation of 0.399-0,614 and internal consistency equal to 0.911. In this research, the data analysis used a bivariate correlation from Pearson and Independent-Samples $t$-Test. Based on the results of Product Moment analysis, it obtained $r=-0.528$ with significance level $p=0.000(p<0.05)$. The result showed that there was a significant negative relationship between career decision-making difficulties and self-efficacy in senior high school students. The result of statistics of independent-samples $t$-test was $F=1.496$ with significance of 0,319 ( $p>0.01)$ and mean value for senior high school students $N$ of 66.14 was higher than the mean value of senior high school students $S$ of 62.44 . The result showed that there was no significance in career decision-making difficulties between public and private senior high school.
\end{abstract}

Keywords: career decision-making difficulties; elf-efficacy.

\section{INTRODUCTION}

Career decision-making in students is the ability process while managing information to make favored decisions for their careers (Willner et al., 2015). Career decision-making in students is important as the preparation to choose majors in higher education. Problems in career decisionmaking in adolescents are commonly related to majors that provide support of knowledge and skills related to the targeted occupations in the future, thus, adolescents will experience difficulties and confusion in determining career decision, either in determining jobs or in pursuing further studies according to the desired career (Germeijs \& Verschueren, 2006a, 2006b, 2007).

The curiosity of adolescents encourages initiative in seeking information about higher education and job prospects following their potential. The importance of career demands adolescents to prepare the best so they will not experience difficulties, and the knowledge that is relevant to career decision-making has become important. Prior to seeking information about careers, individuals must possess confidence when making career decisions. However, various difficulties 
may occur when making career decisions because they have to take consider variations in changes that occur in the work fields (Tansley et al., 2007).

Difficulties occurring in making decisions are functional problems that are common in high school students (Levin et al., 2020). Difficulty in career decision-making is a condition that inhibits individual to determine a decision about a future career, unable to determine the career, and unable to determine career decision that is suitable for oneself (Willner et al., 2015).

Various challenges make it harder for adolescents to make decisions. The difficulty when determining career decision-making is related to how individuals assess their abilities to face these challenges. High school students in determining the right career path in accordance with the stage of career development require self-efficacy to avoid experiencing difficulties in career decisions (Vertsberger \& Gati, 2015).

Self-efficacy is the belief that an individual has about one's capacity to complete and organize a task required to achieve certain results (Bandura, 1997). Students who cannot make decisions about further study and experience confusion preceded by doubt or uncertainty in making decisions (Arjanggi, 2015). This indicates that students' self-efficacy in making decisions plays a significant role in career decision-making so students do not experience difficulties in determining their choices. The difficulty of career decision-making is influenced by dysfunction of career mind, lack of information, self-efficacy, internal and external conflicts (Sidiropoulou-Dimakakou et al., 2012). One factor (Sidiropoulou-Dimakakou et al., 2012) that influences the difficulty of career decision-making is self-efficacy. Adequate self-efficacy emerges when the individual can deal with various obstacles encountered and explore a variety of information needed in determining the decisions to achieve the expectation (Reddan, 2015). Based on those phenomena, the research problems of this study are: (a). Is there a relationship between self-efficacy and difficulty in making career decision-making in high school students? (b). Is there a difference in self-efficacy between public high school students and private high school students? (c). Is there a difference in career decision difficulties for public high school students and private high school students?

METHOD

Table 1.

Distribution of Research Samples by Gender

\begin{tabular}{ccc}
\hline Gender & Number & $\%$ \\
\hline Male & 86 & 44.6 \\
Female & 107 & 55.4 \\
\hline Total & 193 & 100 \\
\hline
\end{tabular}

Table 2.

Distribution of Research Samples by Grade

\begin{tabular}{ccc}
\hline Grade & Number & $\%$ \\
\hline $1^{\mathrm{st}}$ & 128 & 66.3 \\
$2^{\mathrm{st}}$ & 65 & 33.7 \\
\hline Total & 193 & 100 \\
\hline
\end{tabular}


Table 3.

Distribution of Research Samples by Age

\begin{tabular}{ccc}
\hline Age & Number & $\%$ \\
\hline 15 years & 44 & 22.8 \\
16 years & 107 & 55.5 \\
17 years & 40 & 20.7 \\
18 years & 2 & 1 \\
\hline Total & 193 & 100 \\
\hline
\end{tabular}

Table 4.

Distribution of Research Samples by Major

\begin{tabular}{lcc}
\hline \multicolumn{1}{c}{ Major } & Number & $\%$ \\
\hline Social Science & 30 & 15,6 \\
Mathematics and Natural Science & 129 & 66,8 \\
Languange & 34 & 17,6 \\
\hline Total & 193 & 100 \\
\hline
\end{tabular}

\section{Participants}

The subjects of this study were high school students of $1^{\text {st }}$ and $2^{\text {nd }}$ grades. This research involved N High School and S High School in Semarang. The sampling technique of this study used cluster random sampling to determine classes as participants in the study. The total number of participants in this study were 193 students of $1^{\text {st }}$ grade and $2^{\text {nd }}$ grade consisting of 86 male students and 107 female students, with 128 students of $1^{\text {st }}$ grade and 65 students of $2^{\text {nd }}$ grade. The age ranges of participants were 14 students aged 15 years, 107 students aged 16 years, 40 students aged 17 years, and 2 students aged 18 years. Based on the type of participants' majors, 20 students were majoring in social studies (IPS), 129 students majoring in mathematics and natural sciences (MIPA), and 34 students majoring in language. The demographic data distribution of respondents is described in table 1 , table 2 , table 3 , and table 4 .

\section{The Scale of Career Decision-making Difficulty}

This study used the scale of the difficulty of career decision that was adapted by (Arjanggi, 2017) and has been modified in this study by replacing items with low discrimination power in previous studies with new items. Improved items for example in the item of: "I know that I have to choose a career path, but I do not want to do it" is replaced with "I am still confused in choosing a career (job)", "I disagree with my parents about the characteristics of my desired career" is replaced with "I think parents have career choices that are different from mine", "job is not the most important thing in life and I feel relaxed about choosing my career" becomes "I do not care about choosing a career because in my opinion, a job is unimportant", "I believe that I do not have to choose a career for now because time will bring me to the right career path" becomes "I am sure there will be a time when I will get the right career choice (job)," and "I avoid making career decisions" to "I think now is not the time to choose a career (job)".

The aspects used in the scale of difficulty in career decision-making are aspects of career decision-making difficulties according to (Gati et al., 1996); lack of readiness (subcategories: lack of motivation, doubt, dysfunctional belief and lack of knowledge about the career decision-making process), lack of information (subcategories: lack of information about oneself, lack of information 
about work, and lack of information about obtaining additional information), and inconsistent information (subcategories: unclear information, external conflicts, and internal conflicts). The scale form of career decision-making difficulties used 5 answer choices in the form of VA (Very Appropriate), A (Appropriate), N (Neutral), I (Inappropriate), and VI (Very Inappropriate).

\section{Self-Efficiency Scale}

This study used the self-efficacy scale proposed by (Aini, 2015) and has been modified by researchers, which is replacing items with low discrimination power with new items. The selfefficacy scale items improved in this research are: "my ability is disrupted when I am faced with various tasks from school" to "I have no passion to do the task if my friends underestimate my ability", "my success in completing a task does not guarantee my success in other tasks" to "I become disappointed/do not want to attempt harder if I fail in the exam" and "I always need other's help in completing difficult tasks" to "I easily give up when there are difficulties".

The aspects used in the self-efficacy scale are using aspects of self-efficacy according to (Bandura, 1997), namely the level, strength, and generality. The self-efficacy scale used 5 answer choices in the form of VA (Very Appropriate), A (Appropriate), N (Neutral), I (inappropriate), and VI (Very Inappropriate).

\section{Research procedure}

The procedure of this study began with obtaining permission in several institutions, one public school, and one private school in Semarang city. The next stage was the researchers conducted randomly in the classes used as research subjects. Some classes were available at the two schools that were randomly selected to be the subject of a trial-measurement instrument and some were chosen as research subjects. The subject of this study was determined in those two schools. Researchers divided and supervised the scale completion by students who used the Career Counselling class. Before entering the scale trial, the researchers first conducted focus group discussions on five students to identify sentences that might be difficult for senior high school students to understand. The results of the focus group discussion were utilized to revise some sentences that were considered difficult to understand after consulting an expert.

The next stage was to test the measuring instrument to obtain items with high discrimination power that would be used in this research. This study took the sample using the Cluster Random Sampling method, which is random sampling based on groups or classes of the population (Azwar, 2015). The drawing was done to determine the testing subject for measuring instrument and the research subject, these were carried out accompanied by advisor. The selection of class was performed by a random drawing conducted twice by the research supervisor, the first drawing was used for testing the measuring instrument and the second one was used for research. Measuring testing instrument in this study was students of N High School and S High School in Semarang consisting $1^{\text {st }}$ grade Language Major, $2^{\text {nd }}$ grade Social Science $4,1^{\text {st }}$ grade Social Science 2 for $\mathrm{N}$ High School students and $1^{\text {st }}$-grade Mathematics and Natural Science 2, $1^{\text {st }}$ grade Social Science 3, $2^{\text {nd }}$-grade Mathematics and Natural Science 2 for S High School students. On April 26, 2019, the distribution of testing scale was conducted on $2^{\text {nd }}$ grade Mathematics and Natural Science 2 students at 08.00-08.45 WIB. The testing of the measuring instrument was subsequently carried out with the students of class $1^{\text {st }}$ grade Social Science 2 and $2^{\text {nd }}$ grade Social Science 4 . The final test of the measuring instrument was administered on the students of $1^{\text {st }}$ grade Language class, $1^{\text {st }}$ grade Mathematics and Natural Science 2, and $1^{\text {st }}$ grade Social Science. The distributed scales were 185 and completely filled in. The tryout had obtained permission from the senior deputy head, 
counselling teacher, and teacher concerned. The tryout scales filled in by participants were later given a score for data processing and to find the remaining items and canceled items. The results of scale tryout were then be used to compile the scale for the study. The data processing of measuring instrument tryout used SPSS version 20.0 for windows.

The study was conducted on students in S High School consisting of students in class $1^{\text {st }}$ grade Social Science 2 and $1^{\text {st }}$-grade Mathematics and Natural Science 3 during the teachinglearning process. The distributed scales were 62 and completely filled in. The distribution process was performed by entering the classroom accompanied by senior deputy head to ask for class permission during the teaching-learning process. Before filling in the scale, the researcher first did self-introduction, informed the objectives, and explained the guidelines before filling the scale. Next, research was performed on N High School consisting of $1^{\text {st }}$ grade Language major and $2^{\text {nd }}$ grade Mathematics and Natural Science 3 students. The distributed scales were 66 and completely filled in. The distribution process was conducted into class accompanied by a Counselling teacher following his/her teaching hours used for research. Lastly, the research was conducted at $\mathrm{N}$ High School students consisting of class $1^{\text {st }}$-grade Mathematics and Natural Science 2 and $2^{\text {nd }}$-grade Mathematics and Natural Science 2. The distributed scales were 65 and completely filled in. The distribution process was done to the classroom accompanied by a Counselling teacher.

\section{RESULTS AND DISCUSSION}

Based on the test of discrimination power of the item on the scale of the career decisionmaking difficulty, it showed that 5 items had low discrimination power, which was below 0.3 . The reliability index of the scale of career decision-making difficulty was $\alpha=0.960$. In the self-efficacy scale, it was known that 1 item had low discrimination power, which was under 0.3 with the reliability index of self-efficacy scale of $\alpha=0.911$.

The analysis results of the test of variable difference in career decision-making difficulty based on gender obtained an F value of 8.844 with a p-value of $0.003(\mathrm{p}<0.01)$, which implies there was a significant difference. The self-efficacy variable obtained an F value of 1.142 with p-value of 0.286 ( $p>0.05$ ), which means there was no significant difference. The results of the analysis are shown in Table 6.

Table 6.

Descriptive Statistics

\begin{tabular}{cccccccc}
\hline Variable & N & Average & SD & Minimum & Maximum & F & $\boldsymbol{p}$ \\
\hline Self-efficacy & 193 & 80.24 & 13.291 & 35 & 112 & 8.844 & 0.003 \\
Career decision making & 193 & 64.97 & 23.936 & 3 & 142 & 1.142 & 0.286 \\
difficulty & & & & & & & \\
\hline
\end{tabular}

Based on the analysis using hypothetical norms, it was known that 81 percent of adolescents had high self-efficacy, 18 percent had moderate self-efficacy, and 1 percent had low self-efficacy. Complete results regarding self-efficacy in adolescents are presented in table 7.

During the decision-making process, it was known that 16 percent of adolescents encountered difficulty in making career decisions and 35 percent were in a moderate level of career decision-making difficulties. Adolescents encountered a slight difficulty in career decision-making by 38 percent, while adolescents who had no difficulty in career decision-making were 11 percent. Even though adolescents have high self-efficacy, the potential to have a level of difficulty in making decisions still appears. Complete results regarding adolescent in career decision-making difficulties 
are presented in table 8.

Table 7.

Scores Category of Self-Efficacy Scale

\begin{tabular}{cccc}
\hline Norm & Category & Frequency & Precentage \\
\hline $86.999<\mathrm{x}$ & Very High & 60 & $31 \%$ \\
$67.666<\mathrm{X} \leq 86.999$ & High & 97 & $50 \%$ \\
$48.334<\mathrm{X} \leq 67.666$ & Moderate & 34 & $18 \%$ \\
$29.001<\mathrm{X} \leq 48.334$ & Low & 2 & $1 \%$ \\
$\mathrm{X} \leq 29.001$ & Very Low & 0 & $0 \%$ \\
\hline & & 193 & $100 \%$ \\
\hline
\end{tabular}

Table 8.

Score Category of Career Decision-Making Difficulty Scales

\begin{tabular}{|c|c|c|c|}
\hline Norm & Category & Frequency & Precentage \\
\hline $113.999<\mathrm{X}$ & Very High & 4 & $2 \%$ \\
\hline $88.666<X \leq 113.999$ & High & 26 & $14 \%$ \\
\hline $63.334<X \leq 88.666$ & Moderate & 67 & $35 \%$ \\
\hline $38.001<X \leq 63.334$ & Low & 74 & $38 \%$ \\
\hline$X \leq 38.001$ & Very Low & 22 & $11 \%$ \\
\hline \multicolumn{2}{|c|}{ Total } & 193 & $100 \%$ \\
\hline
\end{tabular}

Hypothesis test results correlating the self-efficacy independent variable and career decision-making difficulty dependent variable with Pearson product-moment correlation analysis techniques obtained correlation values $(\mathrm{r}=-0.528)$ with $\mathrm{p}$ values of $0.000(\mathrm{p}<0.05)$, which signifies a significant correlation between two variables. There was no difference found in career decisionmaking difficulty between public and private schools, as the results of the analysis obtained $\mathrm{F}$ value of 0.998 with $p$-value of 0.319 ( $p>0.05$ ), which indicates no significant difference. There was no difference in the self-efficacy variable between public and private schools, as the results of the analysis obtained $F$ value of 0.382 with $p$-value of 0.537 ( $p>0.05$ ), which means no significant difference between the two groups of students.

Based on the analysis of descriptive statistics, it was found that there were differences in self-efficacy based on gender. These findings do not indicate a novel finding, as the previous study also has shown the same results that there are differences in self-efficacy between male and female students, and male students have higher self-efficacy than female students (Löve et al., 2011). The next finding based on gender difference test on the career decision-making difficulty variable found no difference, which is a novelty compared to the previous study which found differences with a higher level of difficulty in female students (Arjanggi, 2017) and the other study which shows that difference in career decision-making difficulty is higher in male students than female students (Levin et al., 2020).

The purpose of this study is to answer the research problem - whether there is a relationship between self-efficacy and career decision difficulty in high school students. The results show that there is a correlation between self-efficacy and career decision-making difficulty, which is $r_{x y}$ result of -0.528 ( $\mathrm{p}<0.01)$. This evidences that there was a negative relationship between self-efficacy with career decision-making difficulty in high school students. This result signifies that the higher the 
student's self-efficacy, the lower the level of difficulty of students in making a career decision is. Also, the lower the student's self-efficacy, the higher the career decision-making difficulty in the student is. The findings of this study indicate the relationship of self-efficacy variable to the level of difficulty in career decision-making in high school students.

The findings of this study are in line with previous research, namely examining the influence of emotional intelligence, self-efficacy, and locus of control on the career decision-making difficulty in high school students of SMA N 47 Jakarta, which shows a relationship between three independent variables, namely emotional intelligence, self-efficacy, and locus of control of career decision-making difficulty (Rahman, 2017). This study found that public high school students and private high school students in Semarang had higher correlation values than previous research.

The same results were also obtained from a study conducted by (Fadhilah, 2015) concerning the effect of self-efficacy, parenting, and attachment to the career decision-making difficulty in high school students in Jakarta. Hypothesis testing on self-efficacy variable with career decision-making difficulty showed a correlation coefficient of -0.332 with a significance of $p=0.000(p<0.05)$. It shows that there is a negative significant relationship between self-efficacy and the career decisionmaking difficulty in students of SMA Negeri 29 Jakarta.

Self-efficacy shows the negative direction of career decision-making difficulty and has a significant influence on career decisions (Ye, 2014). These results may have an impact on students' motivation and perceptions to be more diligent and active because they have high self-efficacy and enable students to be more comfortable when making career decisions, thus, students are able to overcome difficulties (Elliot et al., 1999). Self-efficacy in students can build confidence to be able to determine the right decision for them, so that it will have an impact on students' behavior, such as finding information about favorite majors according to their passion, more active in learning, and more confident to seize their desired majors. Students with low levels of self-efficacy, when they determine their career decisions, it will be difficult for them to make decisions and the lack of confidence in choosing the majors (Taylor \& Betz, 1983).

The results of the second hypothesis test, researchers tested differences in the career decisionmaking difficulty between public high school students and private high school students. Based on a calculation using an independent-sample t-test, it was found 1,496 with a significance level of 0.319 ( $p>0.05$ ) with an average value of private high school students of 66.14 higher compared to the average value of private high school students, which was 62.44 . These results indicate that there is no significant difference in career decision-making difficulty between public high school students and private high school students.

The result from Mongi's (2016) research prove that there is no difference between public and private schools. The t-test calculation was 1.44 with a significance level of 0.169 ( $p>0.01$ ), which means that there was no significant difference between public and private schools based on accreditation scores. Public schools or private schools have a positive impact on student development. However, students must possess a strong personality and high enthusiasm for learning, so that they can succeed in whichever school they are admitted to.

The results of data analysis in this study indicate that the proposed hypothesis is accepted - there is a significant negative relationship between self-efficacy and the career decision-making difficulty in high school students. If students can increase their self-efficacy, the level of difficulty in making career decisions can be minimized. Self-efficacy in this study is in the high category. This result can be seen from the empirical mean score of self-efficacy, which was 80.24 with a percentage of $50 \%$. The career decision-making difficulty in this study is in a low category. This result is shown in the empirical mean score of career decision-making difficulty, which was 64.97 with a percentage 
of $38 \%$. Self-efficacy contributes effectively by $27.8 \%$ to the career decision-making difficulty. This result is shown on the $\mathrm{r}$ squared value of 0.278 .

\section{CONCLUSION}

This study concludes that there was an effect of self-efficacy on the career decision-making difficulty in high school students. High self-efficacy was proven to contribute to the low career decision-making difficulty in students. Moreover, there was no significant difference in career decision difficulty between public high school students and private high school students. Based on the findings of this study, it encourages future researchers to pay attention to other variables related to the career decision difficulty, for instance, parental support, seeking help behavior, and socioeconomic status of parents.

To the Directorate of Research and Community Service of the Directorate General of Research and Development of the Ministry of Research, Technology, and Higher Education for funding PDUPT research in the 2018-2019 period.

\section{REFERENCES}

Aini, F. (2015). Hubungan antara efikasi diri dengan kematangan karir pada siswa SMA Negeri 2 Tegal. http://repository.unissula.ac.id/id/eprint/2904

Arjanggi, R. (2017). Identifikasi permasalahan pengambilan keputusan karir remaja. Psikologika: Jurnal Pemikiran Dan Penelitian Psikologi, 22(1), 28-35. https://doi.org/10.20885/ psikologika.vol22.iss2.art3

Arjanggi, R. (2015). Studi pendahuluan pengembangan karir aspirasi melalui metode mind map. In Selamatkan Indonesia Untuk Indonesia Berkarakter (pp. 21-28). Semarang: Universitas Islam Sultan Agung Semarang. http://research.unissula.ac.id/file/publikasi/210700010/25513. pdf

Azwar, S. (2015). Metode penelitian. Yogyakarta: Pusraka Pelajar.

Bandura, A. (1997). Self-efficacy in changing societies. New York: Cambridge University Press.

Elliot, A. J., Mcgregor, H. A., \& Gable, S. (1999). Achievement goals , study strategies , and exam performance : A mediational analysis. Journal of Educational Psychology, 91(3), 549-563. https://doi.org/10.1037/0022-0663.91.3.549

Fadhilah, D. R. (2015). Pengaruh efikasi diri, pola asuh, dan kelekatan terhadap kesulitan pengambilan keputusan karir siswa sma negeri 29 jakarta. http://repository.uinjkt.ac.id/ dspace/bitstream/123456789/44016/1/DINI RIZKY FADHILAH-FPSI.pdf

Gati, I., Krausz, M., \& Osipow, S. H. (1996). A taxonomy of difficulties in career decision making. Journal of Counseling Psychology, 43(4), 510-526. https://doi.org/10.1037/00220167.43.4.510

Germeijs, V., \& Verschueren, K. (2006a). High school students' career decision-making process: A longitudinal study of one choice. Journal of Vocational Behavior, 68(2), 189-204. https:// doi.org/10.1016/j.jvb.2005.08.004

148 | Self-efficacy and ... 
Germeijs, V., \& Verschueren, K. (2006b). High school students' career decision-making process: Development and validation of the study choice task inventory. Journal of Career Assessment, 14(4), 449-471. https://doi.org/10.1177/1069072706286510

Germeijs, V., \& Verschueren, K. (2007). High school students' career decision-making process: Consequences for choice implementation in higher education. Journal of Vocational Behavior, 70(2), 223-241. https://doi.org/10.1016/j.jvb.2006.10.004

Levin, N., Braunstein-Bercovitz, H., Lipshits-Braziler, Y., Gati, I., \& Rossier, J. (2020). Testing the structure of the career decision-making difficulties questionnaire across country, gender, age, and decision status. Journal of Vocational Behavior, 116. https://doi.org/10.1016/j. jvb.2019.103365

Löve, J., Moore, C. D., \& Hensing, G. (2011). Validation of the Swedish translation of the general self-efficacy scale. Quality of Life Research, 21(7), 1249-1253. https://doi.org/10.1007/ s11136-011-0030-5

Mongi, C. E., \& Hatidja, D. (2016). Perbandingan SMA negeri dan SMA swasta berdasarkan nilai akreditasi dan nilai ujian nasional menggunakan uji-t di kota Manado. Jurnal Ilmiah Sains, 16(2), 91-97. https://doi.org/10.35799/jis.16.2.2016.14255

Rahman, S. A. (2017). Pengaruh kecerdasan emosional, efikasi diri, locus of control terhadap kesulitan pengambilan keputusan karir pada siswali sma negeri 47 jakarta. http://repository.uinjkt. ac.id/dspace/handle/123456789/37376

Reddan, G. (2015). Enhancing students' self -efficacy in making positive career decisions. AsiaPacific Journal of Cooperative Education, 16(4), 291-300. https://wilresearch.uwaterloo.ca/ Resource/View/104

Sidiropoulou-Dimakakou, D., Mylonas, K., Katerina, A., \& Tampouri, S. (2012). Career decisionmaking difficulties, dysfunctional thinking and generalized self-efficacy of university students in Greece. World Journal of Education, 2(1), 117-130. https://doi.org/10.5430/ wje.v2n1p117

Tansley, D. P., Jome, L. M., Haase, R. F., \& Martens, M. P. (2007). The effects of message framing on college students' career decision making. Journal of Career Assessment, 15(3), 301-316. https://doi.org/10.1177/1069072707301204

Taylor, K. M., \& Betz, N. E. (1983). Applications of self-efficacy theory to the understanding and treatment of career indecision. Journal of Vocational Behavior, 22(1), 63-81. https://doi. org/10.1016/0001-8791(83)90006-4

Vertsberger, D., \& Gati, I. (2015). The effectiveness of sources of support in career decisionmaking: A two-year follow-up. Journal of Vocational Behavior, 89, 151-161. https://doi. org/10.1016/j.jvb.2015.06.004

Willner, T., Gati, I., \& Guan, Y. (2015). Career decision-making profiles and career decisionmaking difficulties: A cross-cultural comparison among US, Israeli, and Chinese samples. Journal of Vocational Behavior, 88, 143-153. https://doi.org/10.1016/j.jvb.2015.03.007

Ye, Y. (2014). Role of career decision-making self-efficacy and risk of career options on career 
decision-making of chinese graduates. Psychological Reports, 114(2), 625-634. https://doi. org/10.2466/01.17.PR0.114k20w9 